\title{
Determining Harvester Productivity Curves of Thinning Operations in Birch Stands of Central Europe
}

\author{
Martyna Rosińska, Mariusz Bembenek, Rodolfo Picchio, Zbigniew Karaszewski \\ Andreja Đuka, Piotr S. Mederski
}

\begin{abstract}
Silver birch (Betula pendula Roth) is a popular tree species forming stands in nearly the whole of Europe. In Poland, birch is one of the most representative broadleaved species growing on rather poor soils, very often as a mix species with Scots pine (Pinus sylvestris L.). In Central Europe, birch forms trunk often with sweep, and at the older age with thick branches. Due to that, a harvester thinning operation in birch stands can be challengeable when trying to process logs from the top part of trees, which can finally impact on productivity. The objective of this research was to determine harvester productivity for birch with particular attention to processing of logs from the top part of a tree. The research was carried out in stands of North and North-West Poland. All together 21 tests were completed in 16 stands, in which 9 harvesters were used (8 different models). The mean diameter of harvested trees was $23.7 \mathrm{~cm}$ with the mean height of $21.7 \mathrm{~m}$. Obtained productivity without delays was on average $21.98 \mathrm{~m}^{3} \mathrm{~h}^{-1}$ and varied from as low as 5.14 to maximum $44.66 \mathrm{~m}^{3} \mathrm{~h}^{-1}$, and depended mainly on harvested tree size. It was also confirmed that top diameter of the last log was related to diameter at breast height (DBH). The model developed based on that relationship can be used for prediction of biomass volume from birch stands when harvesters are used for thinning.
\end{abstract}

Keywords: harvester head, tree trunk sweep, thick branches, top log diameter, Betula pendula Roth

\section{Introduction}

Species composition of European forests has changed considerably over the last few decades. Progressive changes in forest management, also in response to changing climatic conditions, promote deciduous species, and further changes are expected in the following decades (Dyderski et al. 2018). On the example of Poland, it is possible to notice an increase in the share of stands with a predominance of deciduous species, currently amounting to $31.5 \%$ (Report ... 2017). It should also be emphasised that, despite the increase in the area of deciduous stands, their share is still lower than that resulting from the habitat structure. This means that the share of these species will continue to increase in the coming years (National ... 1997). This creates an urgent need for the harvesting services market (Bouriaud et al. 2011). Indeed, in the last years in Europe, we have been observing a decline in the interest of employees in taking up work in motor-manual logging. On the other hand, the level of mechanisation of forest work is also increasing by extending the scope of harvesting operations for young stands of first commercial thinning (Mederski et al. 2018b), this aspect being mostly related to the increase in the number of harvesters and forwarders (Mederski et al. 2016). Direct application of these machines (originally designed for coniferous stands) in deciduous forests does not always bring satisfactory results, unless harvesters are used to cut and process young trees (Mederski et al. 2018b). However, the technical solutions used may reduce the quality of the logs, reducing the use of the obtained wood (Karaszewski et al. 2016a, Karaszewski et al. 2016b). On the other hand, there are indications of many positive cutto-length (CTL) technology advancements that have limited impact on remaining stand and soil conditions 
(Bembenek et al. 2013a, Bembenek et al. 2013b, Picchio et al. 2019, Picchio et al. 2020).

The results obtained so far in the harvesting of hardwood species with a harvester confirm the difficulties during timber processing and indicate their variable efficiency (Bigot 2001, Bigot and Cuchet 2003, Cacot et al. 2006, Spinelli et al. 2002, Suchomel et al. 2011, 2012, Zinkevičius et al. 2012, Mederski et al. 2011, Mederski 2013, Bembenek et al. 2015). They are the morphological features of deciduous trees, including the irregular shape of trunks, big crowns, thick branches and expressed butt swelling of the first log i.e. high stump-height diameter that make mechanised logging of deciduous species more difficult than that of conifers (Krpan et al. 2004, Cacot et al. 2006, Suchomel et al. 2012, Mederski 2013, Mederski 2018a). The frequent forks in the top part of a tree and thick branches can reduce the harvester efficiency by 15 to $20 \%$ (Labelle et al. 2016). This has been also confirmed in coppice stands (Schweier et al. 2015, Spinelli et al. 2016). Bucking is another harvesting operation where timing may vary between conifers and deciduous trees. According to Labelle et al. (2019), the higher wood density of the beech trees compared to the density of softwood, as well as the complex crown architecture, contribute to the lower productivity of hardwood harvesting. A positive effect was also observed of the size (diameter) of the harvested tree on the productivity growth, but only to a certain degree (Visser and Spinelli 2012).

Furthermore, among the variables affecting the efficiency of logging, regardless of the type of harvested trees, the operator's experience and motivation are always of importance (Bigot 2001, Bigot and Cuchet 2003, Spinelli 2010). Some harvester operators, even having extensive experience in carrying out harvesting works, previously worked mainly in coniferous stands.

However, considering the above-mentioned growing importance of broadleaved species, silviculture and the highest overall sustainability of fully mechanised harvesting systems (Schweier et al. 2019), introducing harvesters for the utilisation of broadleaved species is a crucial issue for the efficiency of the forest sector.

Silver birch (Betula pendula Roth) covers almost all of Europe with its natural range, except Spain, Greece, and Italy (without the northern fragment). In addition, it occurs in parts of Asia Minor, the Caucasus, and Western Siberia. In Poland, next to oak and beech, it is the most important deciduous species, and the share of birch wood in the total timber harvest is approximatley 9\% (Lachowicz 2010). In poorer forest sites, birch is the most common deciduous species that plays the role of a mixture species of $5-10 \%$. In regenerations, birch is introduced with pine, often in gaps and along boundaries of forest compartments (Jaworski 1995).

Silver birch is an important species also from an economic point of view. Birchwood is widely used primarily for the production of high-quality paper, chipboards, and fibreboards; it is also suitable for veneers, as well as for the production of plywood, furniture, cladding, and parquet (Spława-Neyman and Owczarzak 2006). On the other hand, this species presents some morphological features that make fully mechanised harvesting particularly challenging. In fact, mature birch trunks are generally free of branches up to a height of approximately $12-15 \mathrm{~m}$; however, as other broadleaved species (Karaszewski et al. 2013), it can often have defects in the bottom part, e.g. swelling or sweep (Spława-Neyman and Owczarzak 2006).

Taking into consideration the above-mentioned facts, it can be stated that productivity of harvesters in log processing of broadleaved trees can be lower (Labelle et al. 2016). At the same time it is indicated that there are difficulties in log processing from the top due to sweep, thick branches and forks. However, Mederski (2013) also indicated that high productivity can be achieved when there is no log processing from the top part of the tree (avoiding the challenging part for harvester processing). Based on that, it was hypothesised that there is an optimal point of birch processing to certain top diameter that gives maximum productivity and the best possible use ot tree trunk for logs. Therefore, the aim of of this study was to determine the overall efficiency of harvesting birch wood with harvesters, with particular attention to determine productivity. Additionally, attention was paid to particular challenges in processing of logs from the tree top parts with determination of minimum log diameter.

This study represents the first attempts of scientific evaluation of CTL technology in birch stands of Central Europe. In the present research, the innovative approach was to find out the point of the best efficiency between productivity and utilisation of the trunk for logs (industrial timber).

\section{Materials and Methods}

\subsection{Research Areas and Machines Description}

The research included 21 experimental plots in 16 stands located in 9 forest districts in North Poland (Fig. 1). In the first case, the test was also carried out using variable settings for the harvester engine revolutions 


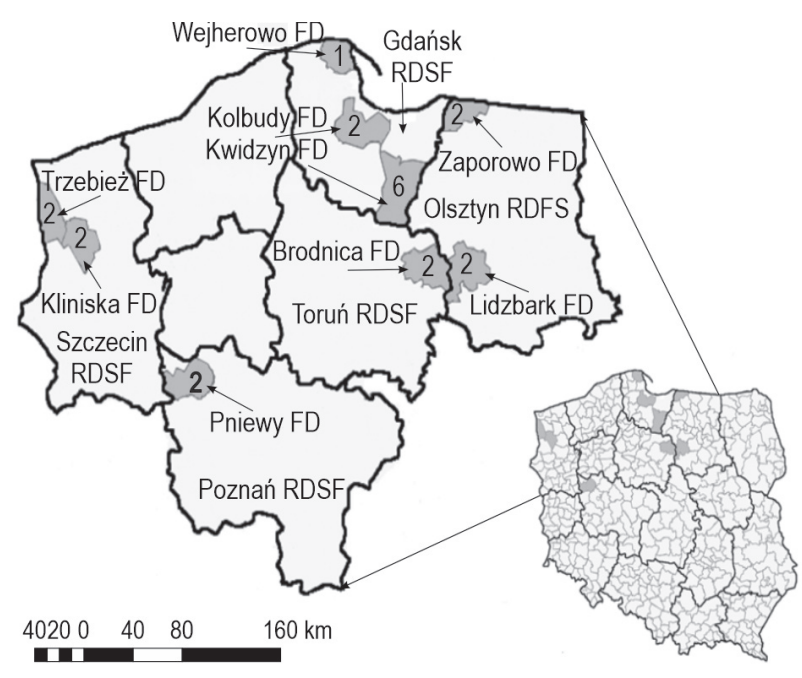

Fig. 1 Research areas located in North and North-West Poland (RDSF - Regional Directorate of the State Forests, FD - Forest District)

(1600/1800 RPM). On four research areas, field studies were carried out twice (two separate sample plots in the same stand): during and after the growing season of trees. The research was carried out during thinning operation in birch stands or in mixed stands with at least a 20\% share of birch. There were all together 3166 birch trees felled for the study and the volume was estimated based on 940 trees, of which the exact timber volume was calculated. Trees were harvested with thinning intensity according to silvicultural treatment: 20 to $30 \%$ of volume of initial stands.
Timber was harvested by forest entrepreneurs currently providing services in selected forest districts. Research areas were selected among stands where birch harvesting was planned. Finally, nine harvesters were selected (but eight models) and nine harvester heads (also 8 models) were tested (Table 1).

\subsection{Data Collection}

Work on selected research areas was divided into two stages:

$\Rightarrow$ tree measurements

$\Rightarrow$ time studies and collecting of timber harvesting data.

All trees planned for felling were marked with paint on both sides of the tree at eye level. On each marked tree selected for cutting, the following measurements were provided:

$\Rightarrow$ diameter at breast height $(D B H)$ - with a calliper, twice crosswise each time in different direction towards north, with an accuracy of $1 \mathrm{~mm}$

$\Rightarrow$ the height of the tree and the height of the base of tree crown were measured - with the Vertex Laser, with an accuracy of $0.1 \mathrm{~m}$ (the tree crown length was defined as the top part of the tree measured from the first living branch connected to the crown or the top of a tree)

$\Rightarrow$ at a height of approx. $1.5 \mathrm{~m}$, the number of the tree was painted.

Table 1 Basic data of the used harvesters

\begin{tabular}{|c|c|c|c|c|c|}
\hline Harvester & $\begin{array}{l}\text { Harvester production } \\
\text { year }\end{array}$ & $\begin{array}{l}\text { Harvester engine } \\
\text { power, kW }\end{array}$ & $\begin{array}{l}\text { Harvester } \\
\text { head }\end{array}$ & $\begin{array}{c}\text { Harvester head size - } \\
\text { maximum cutting diameter, mm }\end{array}$ & $\begin{array}{c}\text { Operator experience } \\
\text { years }\end{array}$ \\
\hline John Deere 1270 D & 2008 & 160 & $758 \mathrm{HD}$ & 650 & 10 \\
\hline John Deere 1270E & 2013 & 170 & H480C & 710 & 9 \\
\hline Ponsse Ergo & 2004 & 176 & H73 & 700 & 3 \\
\hline \multirow{2}{*}{ Ponsse Ergo 6} & 2011 & \multirow{2}{*}{210} & $\mathrm{H} 7$ & 750 & 7 \\
\hline & 2002 & & $\mathrm{H} 73$ & 700 & 4 \\
\hline Sampo Rosenlew 1066 & 2008 & 129 & HTH460 & 620 & 3 \\
\hline TBM Preus 84 & 2003 & 112 & $\begin{array}{l}\text { Kesla } \\
24 \mathrm{RHII}\end{array}$ & 520 & 4 \\
\hline Timberjack 1070D & 2003 & 136 & HTH460 & 620 & 2 \\
\hline Valmet 901.3 & 2007 & 140 & 351.1 & 600 & 7 \\
\hline
\end{tabular}


Preliminary work usually included the entire stand of the whole compartment or in the case of large areas, the experimental trial consisted of approx. 250 trees planned for removal. Timber harvesting was carried out on parallel strip roads distributed at a distance of $20 \mathrm{~m}$ between them.

The second stage of the research involved cutting down trees and processing of assortments. During the harvester work, time study was carried out (with an accuracy of $1 \mathrm{~s}$ ), taking into account three stages of work time:

$\Rightarrow$ TA - driveway to the tree, crane out, head positioning, felling, tree preparation for delimbing

$\Rightarrow \mathrm{TB}$ - start of delimbing and bucking finishing when tree top is cut off

$\Rightarrow$ TC - delays, e.g. chain replacement, minor repairs, telephoning and other breaks.

During the harvesting process, the number of logs and assortments produced by the harvester were recorded. Most of them were papermill logs $2.5 \mathrm{~m}$ long and firewood logs with a length of 1 or $2 \mathrm{~m}$. Occasionally, in the best quality stands, large-size logs were also processed, the length of which was determined by the operator directly upon information from the harvester computer screen. To calculate the total length of logs from one tree, all the processing assortments and wood residues (tree tops) from a single tree were laid separately on the cutting area.

Upon completion of tree felling and processing, the obtained timber was measured. For a minimum of 30 consecutive trees with visible number on the first log, the lengths of all assortments (with an accuracy of $1 \mathrm{~cm}$ ) and the upper diameters of the top log (under bark, twice crosswise, with an accuracy of $1 \mathrm{~mm}$ ) were measured to obtain logs volume.

\subsection{Data Analysis}

The timber volume obtained from a single tree was divided into 3 categories:

$\Rightarrow$ a total merchantable timber volume processed by a harvester

$\Rightarrow$ an unprocessed merchantable timber volume (up to $5 \mathrm{~cm}$ under bark at the top, thinner end)

$\Rightarrow$ an energy biomass volume with the size less than $5 \mathrm{~cm}$ diameter under bark.

The volume $\left(V, \mathrm{~m}^{3}\right)$ was calculated based on the Huber's formula:

$$
V=\frac{\pi \times d^{2} \times l}{40.000}
$$

Where:

d mid-point diameter under bark, $\mathrm{cm}$

$l$ total log length, $\mathrm{m}$.

The mid-length diameter under bark was determined upon top log diameter and tree taper - degree to which a tree stem or bole decreased in diameter $\left(C_{\text {sort }} \mathrm{cm} \mathrm{m}^{-1}\right)$ and for the unprocessed top length $\left(C_{\text {top }}\right.$ $\left.\mathrm{cm} \mathrm{m}^{-1}\right)$ :

$$
\begin{gathered}
C_{\text {sort }}=\frac{D B H-d t l}{t l l-1,3} \\
C_{\text {top }}=\frac{d t l}{u t l}
\end{gathered}
$$

Where:

$\mathrm{DBH}$ diameter at breast height under bark, $\mathrm{cm}$

$d t l$ diameter of top log under bark, $\mathrm{cm}$

tll total log length, $\mathrm{m}$

utl unprocessed top length, $\mathrm{m}$.

The timber volume processed by a harvester and the time study were used to calculate the operational productivity $\left(P, \mathrm{~m}^{3} \mathrm{~h}^{-1}\right)$, including the effective time (without delays):

$$
P=\frac{V_{\text {sort }}}{T_{\mathrm{A}}+T_{\mathrm{B}}}
$$

Where:

$V_{\text {sort }} \quad$ timber volume processed by a harvester, $\mathrm{m}^{3}$

$T_{\mathrm{A}} \quad$ total of work time category $\mathrm{A}, \mathrm{h}$

$T_{B} \quad$ total of work time category $B, h$.

Statistical analyses were carried out with StatisticaTM version 7.1 (TIBCO Software Inc., Palo Alto, CA, USA). Data distribution was plotted and checked for normality and homogeneity of variance using the Lilliefors and Levene tests, respectively. Descriptive plots data were analysed using MANOVA to test for significant multivariate effects between the plots. The Tukey HSD test was used to pinpoint differences on specific differences between the plots; this post hoc multiple comparison of means test was applied at the $95 \%$ family-wise confidence level ( $p=0.05)$. Linear and non-linear, simply and multiple regression analysis was applied to test the factors affecting the level of harvesters productivity. In particular, a stepwise forward analysis was done for the multiple regression analysis in order to select the more predictive independent variables. The Pearson's coefficient was used to check the correlation between the presented variables. 


\section{Results}

The mean productivity of all sample plots amounted to $21.98 \mathrm{~m}^{3} \mathrm{~h}^{-1}$, and it varied between 5.14 and $44.66 \mathrm{~m}^{3} \mathrm{~h}^{-1}$ (Table 2). Low value was from a trial made in young, 28-y.o. stand with a mean diameter of $12.7 \mathrm{~cm}$. The highest productivity was achieved in 58-y.o. stand with harvested trees of mean $D B H$ of $30.3 \mathrm{~cm}$. It is worth noticing that harvester productivity was not correlated with stand age, but harvested tree mean $D B H$. The obtained logs were processed up to $11.7 \mathrm{~cm}$ under bark (top diameter of the last log from tree crown), while it was aimed to process logs from tree tops up to $5 \mathrm{~cm}$ under bark. In any case, $11.7 \mathrm{~cm}$ was

Table 2 Parameters of harvesting effectiveness and main characteristics of harvested trees with MANOVA and Tukey test results $p<0.05$ (different letter showed different average groups)

\begin{tabular}{|c|c|c|c|c|c|c|c|c|}
\hline Sample plot & $\begin{array}{c}\text { Productivity } \\
\mathrm{m}^{3} \mathrm{~h}^{-1}\end{array}$ & $\begin{array}{l}\text { Diameter of the } \\
\text { top log, } \mathrm{cm}\end{array}$ & $\begin{array}{c}\text { Share of tree crown } \\
\text { used for logs, } \%\end{array}$ & $\begin{array}{l}\text { Volume of merchantable } \\
\text { timber not used for logs, } \%\end{array}$ & $\begin{array}{c}\text { Forest stand } \\
\text { age, years }\end{array}$ & $D B H, \mathrm{~cm}$ & Height, $\mathrm{m}$ & $\begin{array}{l}\text { Height of the } \\
\text { crown, } m\end{array}$ \\
\hline 1 & 13.73 & $10.0 \mathrm{a}$ & 33.40 & $10.18 \mathrm{a}$ & 59 & $20.4 \mathrm{a}$ & $19.6 \mathrm{a}$ & $12.0 \mathrm{a}$ \\
\hline 2 & 30.30 & $12.3 b$ & 34.66 & $8.35 b$ & 56 & $27.0 \mathrm{~b}$ & $23.9 b$ & $14.3 \mathrm{~b}$ \\
\hline 3 & 19.60 & $10.8 \mathrm{a}$ & 34.57 & $7.10 \mathrm{~b}$ & 71 & $22.0 \mathrm{a}$ & $20.7 \mathrm{a}$ & $12.5 \mathrm{a}$ \\
\hline 4 & 41.05 & $14.7 \mathrm{c}$ & 34.79 & $5.82 \mathrm{c}$ & 79 & $33.5 c$ & $25.4 \mathrm{c}$ & $16.5 c$ \\
\hline 5 & 12.01 & $10.5 \mathrm{a}$ & 29.56 & $10.92 \mathrm{a}$ & 53 & $19.2 \mathrm{a}$ & $19.2 \mathrm{a}$ & $11.4 \mathrm{a}$ \\
\hline 6 & 12.35 & $10.6 \mathrm{a}$ & 18.46 & $11.20 \mathrm{a}$ & 73 & $23.9 \mathrm{a}, \mathrm{b}$ & $22.0 \mathrm{a}, \mathrm{b}$ & $14.7 \mathrm{~b}$ \\
\hline 7 & 13.60 & $9.8 \mathrm{a}$ & 39.72 & 6.27 b, c & 63 & $20.8 \mathrm{a}$ & $19.5 \mathrm{a}$ & $11.2 \mathrm{a}$ \\
\hline 8 & 19.17 & $14.2 \mathrm{c}$ & 31.35 & $7.06 \mathrm{~b}$ & 66 & $32.1 \mathrm{c}$ & $23.2 \mathrm{~b}$ & $13.9 b$ \\
\hline $9 \mathrm{LR}$ & 28.43 & $13.8 \mathrm{c}$ & 25.18 & $8.91 \mathrm{~b}$ & 64 & 30.2 b, c & $23.8 b$ & $13.4 \mathrm{~b}$ \\
\hline $10 \mathrm{HR}$ & 29.98 & 13.0 b, c & 12.65 & $9.25 a, b$ & 64 & $28.9 \mathrm{~b}$ & $23.9 b$ & $14.1 \mathrm{~b}$ \\
\hline 11 & 23.58 & $8.6 \mathrm{a}$ & 48.18 & $5.98 \mathrm{c}$ & 52 & $21.0 \mathrm{a}$ & $19.8 \mathrm{a}$ & $12.2 \mathrm{a}$ \\
\hline 12 & 17.07 & $11.5 \mathrm{a}, \mathrm{b}$ & 29.28 & $11.17 \mathrm{a}$ & 69 & $21.3 \mathrm{a}$ & $20.5 \mathrm{a}$ & $12.5 \mathrm{a}$ \\
\hline $13 \mathrm{WL}$ & 15.79 & $13.4 b$ & 17.00 & $15.62 d$ & 48 & $21.9 \mathrm{a}$ & $23.4 b$ & $14.2 b$ \\
\hline $14 \mathrm{NL}$ & 13.28 & $10.8 \mathrm{a}$ & 29.63 & 7.98 b & 48 & $21.2 \mathrm{a}$ & $22.3 \mathrm{a}, \mathrm{b}$ & $13.1 \mathrm{~b}$ \\
\hline $15 \mathrm{WL}$ & 13.28 & $11.3 \mathrm{a}$ & 16.02 & $14.44 d$ & 70 & $20.9 a$ & $22.0 \mathrm{a}, \mathrm{b}$ & $14.6 \mathrm{~b}$ \\
\hline $16 \mathrm{NL}$ & 19.08 & $10.2 \mathrm{a}$ & 18.26 & $7.89 b$ & 70 & $19.0 \mathrm{a}$ & $21.1 \mathrm{a}$ & 15.0 b, c \\
\hline $17 \mathrm{WL}$ & 44.66 & $13.3 b$ & 36.20 & $11.02 \mathrm{a}$ & 58 & 30.3 b, c & $23.9 \mathrm{~b}$ & $15.6 \mathrm{c}$ \\
\hline $18 \mathrm{NL}$ & 41.97 & $12.0 \mathrm{a}, \mathrm{b}$ & 27.86 & $11.83 \mathrm{a}$ & 58 & $25.7 b$ & $22.1 \mathrm{a}, \mathrm{b}$ & $14.0 \mathrm{~b}$ \\
\hline $19 \mathrm{WL}$ & 20.10 & $13.8 \mathrm{c}$ & 23.88 & $11.97 \mathrm{a}$ & 50 & $22.2 \mathrm{a}$ & $21.2 a, b$ & $12.4 \mathrm{a}$ \\
\hline $20 \mathrm{NL}$ & 27.46 & $12.9 \mathrm{a}, \mathrm{b}$ & 41.12 & 6.97 b, c & 50 & $23.9 \mathrm{a}, \mathrm{b}$ & $21.3 \mathrm{a}, \mathrm{b}$ & $13.2 \mathrm{~b}$ \\
\hline 21 & 5.14 & $7.3 d$ & 34.14 & 10.94 a & 28 & $12.7 \mathrm{~d}$ & $16.7 \mathrm{c}$ & $10.2 d$ \\
\hline $\begin{array}{l}\text { MANOVA } \\
p \text {-value }\end{array}$ & & $<0.001$ & & $<0.001$ & & $<0.001$ & $<0.001$ & $<0.001$ \\
\hline $\bar{x}$ & 21.98 & 11.7 & 29.33 & 9.57 & 59 & 23.7 & 21.7 & 13.4 \\
\hline Minimum & 5.14 & 7.3 & 12.65 & 5.82 & 28 & 12.7 & 16.7 & 10.2 \\
\hline Maximum & 44.66 & 14.7 & 48.18 & 15.62 & 79 & 33.5 & 25.4 & 16.5 \\
\hline Median & 19.17 & 11.5 & 29.63 & 9.25 & 59 & 22 & 22 & 13.4 \\
\hline $\begin{array}{l}\text { Standard } \\
\text { deviation }\end{array}$ & 10.81 & 1.9 & 9.15 & 2.71 & 12 & 5.1 & 2.1 & 1.5 \\
\hline
\end{tabular}

LR - low revolutions $=1600$ RPM (revolutions per minute)

$\mathrm{HR}-$ high revolutions $=1800 \mathrm{RPM}$

$\mathrm{WL}-$ with leaves $=$ during vegetation season

$\mathrm{NL}-$ no leaves $=$ after vegetation season 
recognised as effective processing of birch, taking into account tree crowns with thick branches and sweep of trunks.

When tree tops were analysed, it was found out that in average only $9.57 \%$ of merchantable timber volume was left as not processed due to thick branching and sweep.

Higher RPM (1800 RPM) resulted in higher productivity, even if the mean diameter of harvested trees was slighlty smaller (Table 2). Higher RPM also enabled more effective processing of logs from the top parts of the tree (up to $13.0 \mathrm{~cm}$ in comparison with 13.8 cm when 1600 RPM was used). In two cases out of four, higher productivity was achieved when harvesting was carried out after growing season, when trees were without leaves (Table 2).

Productivity depended on $D B H$ of harvested trees - the larger $D B H$ of felled tree, the higher productivity (Fig. 2), which has already been proved by Mederski et al. (2016). In the present study, the relationship between productivity and $D B H$ was confirmed by Pearson's correlation $r=0.57$ (Fig. 2).

This relationship was also characterised by a linear model that showed that the larger $D B H$, the higher deviation of productivity was observed (Table 3). Larger data dispersion was observed for trees of $D B H>20 \mathrm{~cm}$, which affected the magnitude of $R^{2}$. Very high productivity was also calculated for some trees, e.g. $100 \mathrm{~m}^{3} \mathrm{~h}^{-1}$, which was affected by either thick tree (but not the thickest) or the reduced operational time due to cutting next tree from the same machine position (without driving up to the tree) and processing long logs from the bottom part of the tree with reduced processing of logs from the top of the tree.

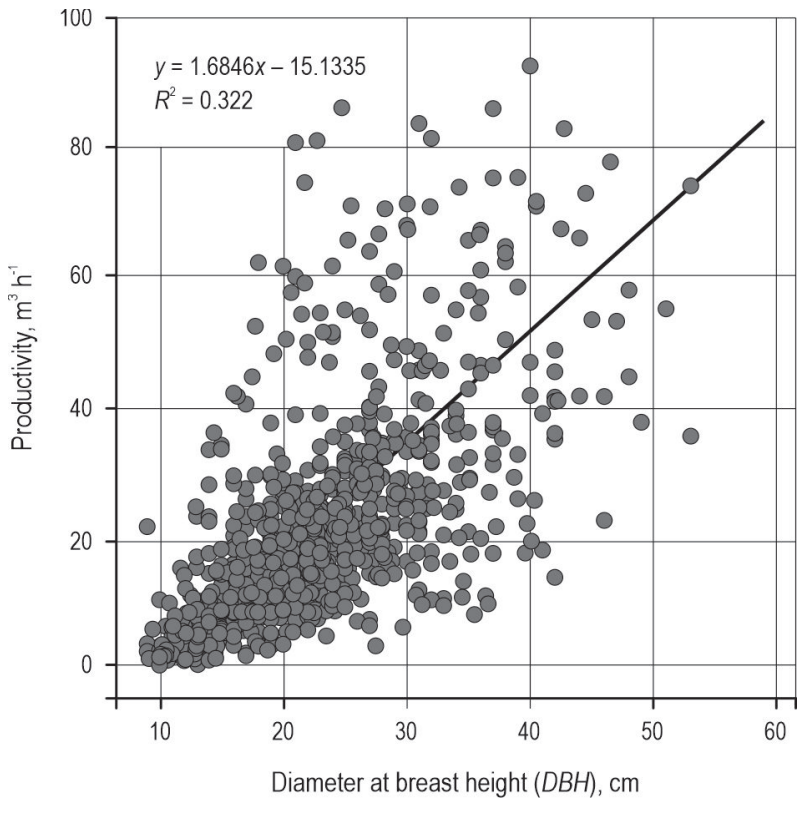

Fig. 2 Productivity model related to $D B H$

Simple linear regression analysis was used in order to understand data distribution and trend; the stepwise analysis was done in the multiple regression analysis, implemented after the considerations obtained by simple regressions (Table 4 ).

When logs were processed from the top of the trees (model $Y$ ), slightly higher productivity was achieved in comparison with the trees for which processing was stopped below the first living branch of the crown (model N, Fig. 3). This reletionship was observed on trees with $D B H$ larger than $30 \mathrm{~cm}$. In models $Y$ and $N$,

Table 3 Linear regression analysis results

\begin{tabular}{|c|c|c|c|c|c|c|}
\hline Productivity vs. DBH & \multicolumn{6}{|c|}{$R=0.566-R^{2}=0.321-R^{2}$ Adj. $=0.320-F(1,938)=442.53-p<0.0001-$ Est. Std. Err.: 19.769} \\
\hline Description & $\beta$ & $\beta$ Std. Err. & Coefficient value (Cv) & Cv Std. Err. & $t(938)$ & $p$-level \\
\hline Intercept & - & - & -15.1335 & 1.920 & -7.883 & $<0.0001$ \\
\hline$D B H$ & 0.566 & 0.027 & 1.685 & 0.080 & 21.037 & $<0.0001$ \\
\hline$d t /$ vs. $D B H$ & \multicolumn{6}{|c|}{$R=0.735-R^{2}=0.540-R^{2}$ Adj. $=0.540-F(1,938)=1101.00-p<0.0001-$ Est. Std. Err.: 2.540} \\
\hline Intercept & - & - & 3.6760 & 0.247 & 14.902 & $<0.0001$ \\
\hline$D B H$ & 0.735 & 0.022 & 0.3414 & 0.010 & 33.182 & $<0.0001$ \\
\hline Productivity vs. $d t /$ & \multicolumn{6}{|c|}{$R=0.400-R^{2}=0.160-R^{2}$ Adj. $=0.158-F(2,937)=89.133-p<0.0001-$ Est. Std. Err.: 21.995} \\
\hline Intercept & - & - & -25.3302 & 5.951 & -4.257 & $<0.0001$ \\
\hline$d t /$ & 0.896 & 0.142 & 5.7387 & 0.910 & 6.304 & $<0.0001$ \\
\hline$\left.d t\right|^{2}$ & -0.524 & 0.142 & -0.1191 & 0.032 & -3.683 & $<0.0001$ \\
\hline
\end{tabular}


Table 4 Multivariable linear regression analysis (with 4 classic variables), $F_{\text {in }}(0.001), F_{\text {out }}(0)$, number of passes $6 . D B H$, tree height, $d t /$ and $\checkmark$ were considered as independent variables

\begin{tabular}{|c|c|c|c|c|c|c|}
\hline \multicolumn{6}{|c|}{ Dependent variable: $P$ (productivity) $R=0.599-R^{2}=0.359-R^{2}$ Adj. $=0.357-F(3,910)=169.66-p<0.001$ Est.Std. Err.: 19.429} \\
\hline & $\beta$ & $\beta$ Std. Err. & $B$ & $B$ Std. Err. & $t$ (937) & $p$-level \\
\hline Intercept & - & - & 6.004 & 3.400 & 1.766 & 0.078 \\
\hline$V$ & 0.548 & 0.075 & 45.722 & 6.305 & 7.251 & $<0.001$ \\
\hline$d t l$ & -0.079 & 0.039 & -0.507 & 0.253 & -2.006 & 0.045 \\
\hline$D B H$ & 0.110 & 0.081 & 0.329 & 0.240 & 1.369 & 0.171 \\
\hline
\end{tabular}

correlations were $r=0.52$ and $r=0.60$, respectively, with not statistically significant differences. Determination factor $R^{2}$ of $Y$ model was lower, which means that processing of logs from tree part with branches (crown) may also lead to higher productivity.

Strong correlation, $r=0.73$, was confirmed between $D B H$ and $d t l$ of the last, top log (Fig. 4) with linear model characterised by high determination factor, $R^{2}=0.54$. This result suggests that knowing the mean birch stand $D B H$ of harvested trees (or all trees before harvesting), it is possible to predict the share of assortments in relation to logging residues.

Even though there was a relationship between $d t l$ and $D B H$, the development of productivity model based on $d t l$ was not satisfactory due to low correlation

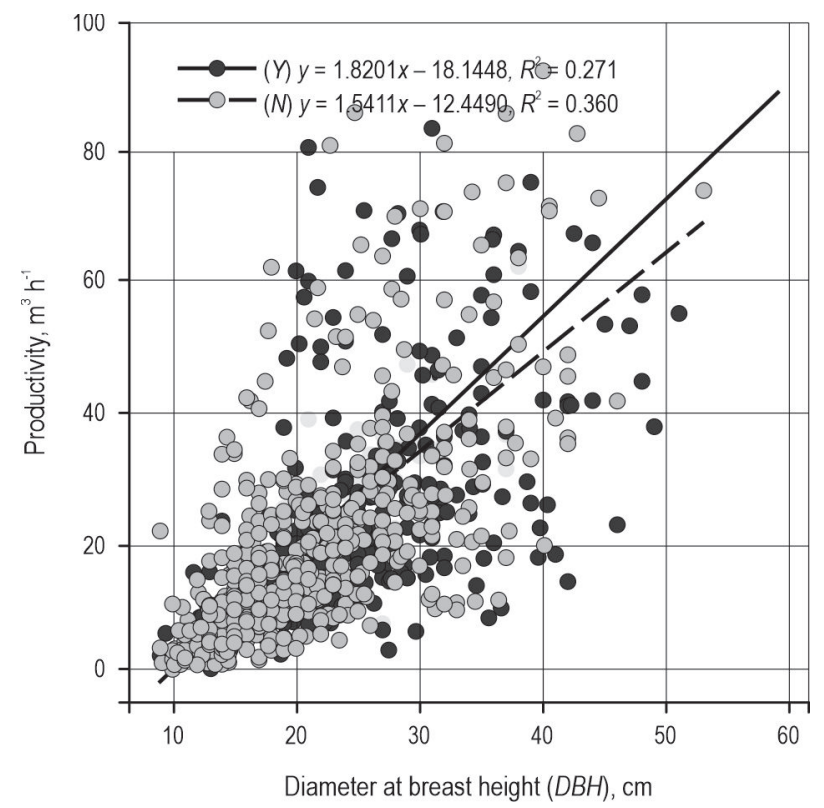

Fig. 3 Productivity models as functions of $D B H$ for: 1) trees from

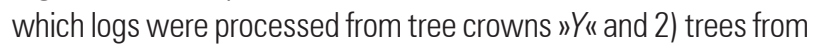
which logs were not processed from tree crowns »N" factor, $r=0.38$. However, the analysis of quadratic model (Fig. 5) shows that leaving substantial, thick top tree residues with top log upper diameter of ca. $20 \mathrm{~cm}$ may impact negatively on productivity. In other words, trials to process logs from top tree parts of smaller diameter than $20 \mathrm{~cm}$ may have positive impact on productivity, even if there are challenging conditions for delimbing.

In the analysed studies of CTL thinning operations in birch stands, productivity mainly depended on DBH of harvested trees, which is also observed in coniferous stands (Mederski et al. 2016). However, in birch stands, productivity also depended on the point on the tree trunk where processing was stopped. Basically, forceful processing of logs from top tree parts

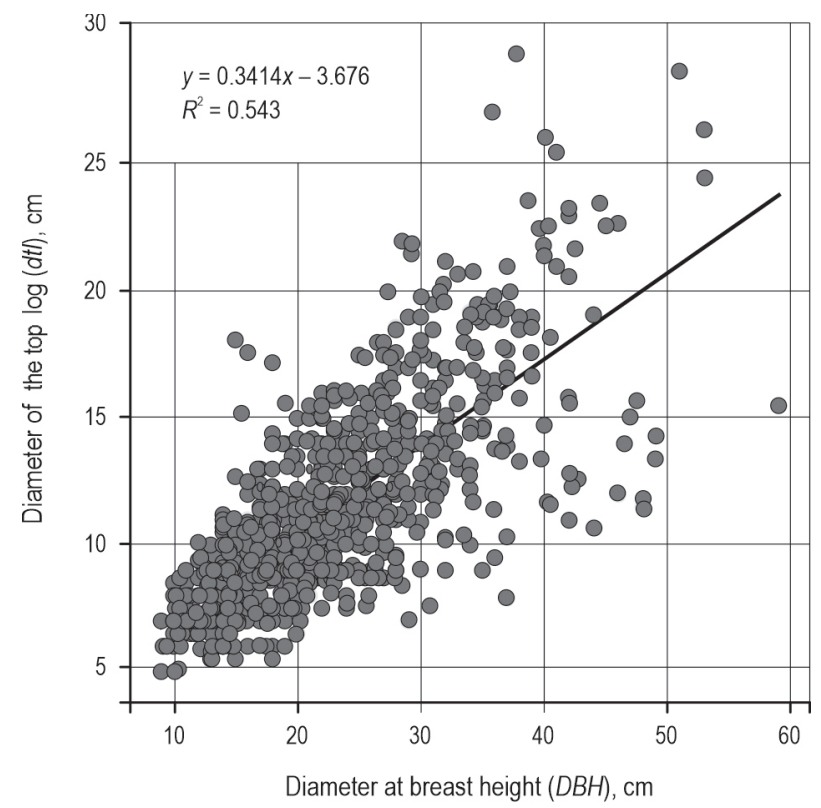

Fig. 4 Model describing relationship of top diameter of the top log (dt/) to $D B H$ of harvested tree 


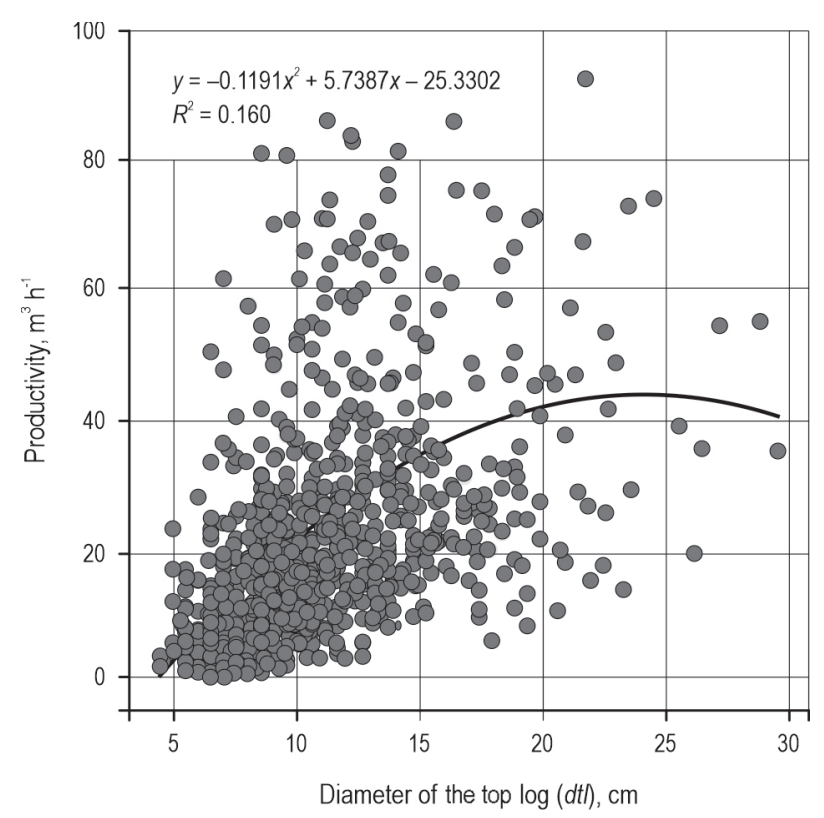

Fig. 5 Productivity model as function of top diameter of the top log $(d t)$

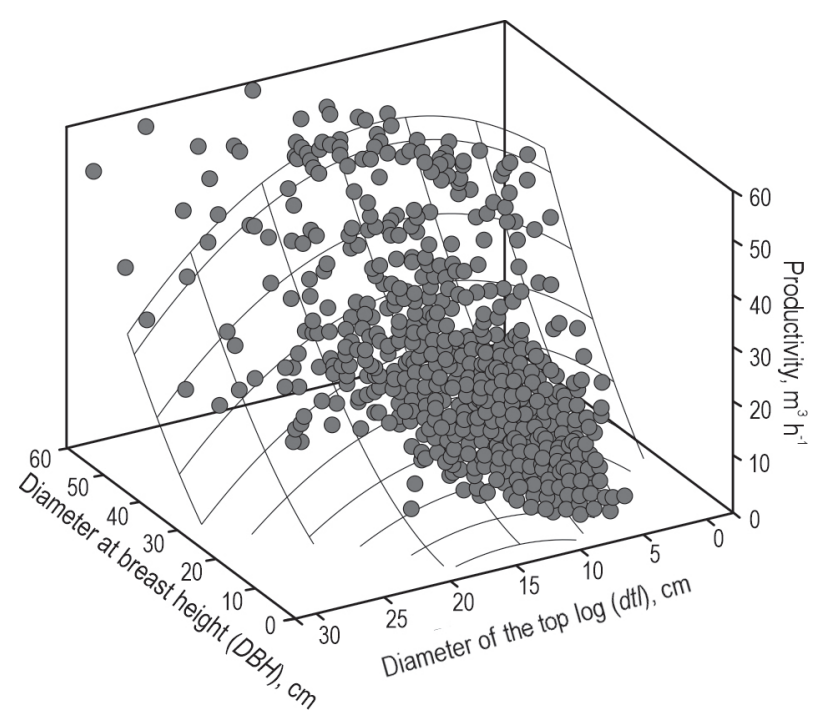

Fig. 6 Productivity 3D model: $f(x, y)=-19.2+0.623 x+2.79 y$ $-0.019 x y+0.026 x^{2}-0.092 y^{2}$ based on two variables: $D B H$ (as $x$ in model) and top log upper diameter (dtl, as $y$ in model)

with thick branches may influence negatively harvester productivity due to time wasted on processing of thin logs (up to $5 \mathrm{~cm}$ under bark). 3D model of two variables: $D B H$ and $d t l$ (Fig. 6) shows that harvesting of trees with largest $D B H$ (within a given range) will be the most productive while processing logs from top tree parts up to at least $20 \mathrm{~cm}$ over bark (Fig. 6).

\section{Discussion}

High harvester productivity has been achieved during thinning operations in birch stands. However, this high effectiveness had a consequence of a substantial amount of harvesting residues left after the processing of logs. Difficulties in delimbing of thick branches and observed sweep lead the operator to decide to stop with log processing at larger top diameters and leave larger tree tops as residues thicker than $5 \mathrm{~cm}$ under bark (aimed diameter for log processing).

The obtained results have shown that nearly $10 \%$ of merchantable timber ( $D B H$ larger than $5 \mathrm{~cm}$ under bark) was left as residues. That was mainly due to the fact that tested harvesters' heads were not able to effectively delimb those trees due to large, developed crowns, thick branches and sweep. These findings are in accordance with previous research by Vusić et al. (2018), who identified time to process the crown as the key factor influencing the productivity (apart from $D B H$ ), which amounts up to $75 \%$ of the total processing time. Similar relationship was described by Suchomel et al. (2012), who proved that size of the branches and stem shape significantly affected machine productivity. Krč et al. (2015) and Danilović et al. (2011) reported that forked trees will lead to significant challenges with processing, because feed rollers and cutting knives may not be able to provide enough force for successful branches removal, which in the end led to lower productivity. It can be concluded that stubborn processing of top tree parts would lead to time consuming operation and further drop in productivity. At the same time, the results have shown that appropriate sylviculture treatments eliminating trees with large tree crowns and forks and selecting progeny with thin branches can support mechanised thinning operations in the future.

Log processing of tree crowns (over living tree branch as a part of tree crown) was only observed in $23 \%$ of cases and delimbing was stopped when $29 \%$ of tree crown length was turned into logs. In the end it was also possible to achieve very high productivity over $40 \mathrm{~m}^{3} \mathrm{~h}^{-1}$ with an average of $22 \mathrm{~m}^{3} \mathrm{~h}^{-1}$.

When higher engine RPM was in use (1800 instead of $1600 \mathrm{RPM}), 5 \%$ higher productivity was achieved, even though thinner trees were cut when higher RPM was used.

Harvesting of trees without leaves also seems to be more effective as higher productivity was achieved in comparison with harvesting of trees during growing season, namely higher by $44 \%$ (sample plots $16 \mathrm{NL}$ and $15 \mathrm{WL}$ ) and $37 \%$ (sample plots 20NL and 19WL). In two cases this result was not achieved, and lower productivity was obtained when cutting trees without leaves. 
However, this productivity was lower by $16 \%$ (sample plots $14 \mathrm{NL}$ and $13 \mathrm{WL}$ ) and $6 \%$ (sample plots $18 \mathrm{NL}$ and 17WL; Table 2). Further studies are recommended to find out if there are other factors influencing these differences.

In three trials, with the best use of timber for logs (Table 2), there were significant differences in age, $D B H$, upper diameter of top log and productivity. In the oldest stand with the biggest mean $D B H$ of harvested trees, processing was stopped at $14.7 \mathrm{~cm}$. In contrast, in younger stands, with mean $D B H$ of harvested trees of 21.0 and $20.8 \mathrm{~cm}$, logs were processed up to 8.6 and $9.8 \mathrm{~cm}$, respectively. It can be concluded that the oldest and thickest trees (in this study) produce thick branches that block effective delimbing.

In comparison to the present research, it was found that larger trees and intensive thinning lead to high productivity in pine stands (Mederski et al. 2016), which can also be observed in clear cuts of very dense growths of willow (Salix sp.) and alder (Alnus sp.). In contrast, large tree crowns, time spent for site preparation or work provided by inexperienced operator can lead to low productivity (Krpan and Prošinsky 2004). Data dispersion from productivity curve suggests that in birch stands there are other factors than $D B H$ of harvested trees that have impact on productivity. The share of tree crown used for logs is one of these factors. It could be concluded that, when processing logs from the bottom, thick parts of tree trunks guarantee high productivity. Processing logs from tree tops may in some cases have a positive impact on the harvester productivity (Fig. 2). Nevertheless, there are still cases where lower productivity is achieved when processing logs from tree tops, which again suggests that, most probably, there are difficulties with delimbing and time waste in that process. This may explain less frequent harvester use in broadleaved stands (Mederski et al. 2016). During the field studies presented in this paper, it was observed that, when the first living branch was the thickest - it was very often a reason to stop with the delimbing process. In case when thin branches were in the crown - continuing with log processing had positive impact on the productivity growth.

$D B H$ was related to the size of upper diameter of the last, top log. It was presented in the model that the thicker the tree, the larger upper diameter of top log, and in the end more residues were left. This information can be used when planning harvesting in thinnings by taking into consideration the share of volume of industrial timber and energy wood (obtained from harvesting residues). In overall, it can be stated that expectation of full use of merchantable timber is not feasible at this moment as available harvester heads will not be able to produce logs up to $5 \mathrm{~cm}$ under bark, due to birch trees morphology. At the same time, very lavish harvesting leaving tree parts thicker than $20 \mathrm{~cm}$ will impact negatively on harvester productivity. Taking that into consideration, productivity results obtained can be seen as economically satisfactory. It is also worth adding that all harvested timber was sold as sawmill timber and pulp wood with no complains or claiming refund. The obtained results suggest that, at this stage of harvester head development, it is wise to find out good, economical and profitable use of $10 \%$ residues from tree tops for energy wood rather than leading to full, doubtfull merchantable timber use for logs (up to $5 \mathrm{~cm}$ under bark), thus probably lowering productivity and expanding processing time of timber with overgrown crowns and thick branches.

The obtained results are also important when productivity is evaluated upon volume of merchantable timber from standing trees (calculated from $D B H$ and height). The results presented in this paper have shown that, using this variant of volume calculation, productivity would be higher than it was in reality. This shows that, when estimating productivity curves, caution has to be taken when merchantable timber is not fully processed by a harvester.

\section{Conclusions}

Processing logs from tree tops in some cases had a positive impact on the productivity level; however, when the first living branch was the thickest, it was very often a reason to stop with the delimbing process. Looking for compromise between trials of logs preparation from tree tops and achieving satisfactory productivity is a new challenge in harvester use in birch stands. Difficulties in delimbing of thick branches, trunks with sweep or large tree crowns discussed in this research led to the decision to stop processing of logs in the top part of the tree, thus leaving larger ( $>5 \mathrm{~cm}$ under bark) residues.

Summarizing, this study represents the first trial of evaluating fully mechanised harvesting of silver birch. The major issues related to harvesters use in birch stands suggest that there is an optimal point between taking the thickest part of the trunk for logs and trial to process logs from the top part of the tree - with no compromise to productivity. Indeed, thick branches and trunk sweep often led to reduced productivity related to processing operation, leading to ca. $10 \%$ volume of not processed industrial timber. On the other hand, harvester productivity in birch stands of Central Europe can reach satisfactory values of maximum $44.66 \mathrm{~m}^{3} \mathrm{~h}^{-1}$ and a mean value of $21.98 \mathrm{~m}^{3} \mathrm{~h}^{-1}$. 


\section{Acknowledgements}

The paper is based on results obtained from the project: The potential of harvester application for hardwood species, EO-2717-22/13, financed by the General Directorate of the State Forests, 2013-2016. The publication was co-financed within the framework of the Polish Ministry of Science and Higher Education programme: »Regional Initiative Excellence« in the years 2019-2022, Project No. 005/ RID/2018/19.

\section{References}

Bembenek, M., Giefing, D.F., Karaszewski, Z., Mederski, P.S., Szczepańska-Álvarez, A., 2013a: Tree damage in lowland spruce stands caused by early thinnings. Sylwan 157(10): 747-753.

Bembenek, M., Giefing, D.F., Karaszewski, Z., Mederski, P.S., Szczepańska-Álvarez, A., 2013b: Tree damage in lowland spruce stands because of late thinning. Sylwan 157(12): 892-898.

Bembenek, M., Mederski, P.S., Karaszewski, Z., Łacka, A., Grzywiński, W., Węgiel, A., Giefing, D.F., Erler, J., 2015: Length accuracy of logs from birch and aspen harvested in thinning operations. Turk. J. Agric. For. 39(6): 845-850. https://doi.org/10.3906/tar-1406-39

Bigot, M., Cuchet, E., 2003: Mechanized harvesting system for hardwoods. In: $2^{\text {nd }}$ Forest Engineering Conference, Växjö, Sweden. SkogForsk, Arbetsrapport 537. ss. 57-66. http:// www.cuchet.eu/IMG/pdf/mechanised_harvesting_system_ for_hardwoods.pdf (accessed 22.04.2014)

Bigot, M., 2001: Using machines to harvest hardwoods in France. Council on Forest Engineering (COFE), Snowshoe. http://web1.cnre.vt.edu/forestry/cofe/documents/2001/ COFE_2001_Bigot.pdf (accessed 24.04.2014)

Bouriaud, L., Kastenholz, E., Fodrek, L., Karaszewski, Z., Mederski, P., Rimmler, T., Rummukainen, A., Sadauskiene, L., Salka, J., Teder, M., 2011: Policy and Market-related Factors for Innovation in Forest Operation Enterprises. W: Weiss, G., Pettenella, D., Ollonqvist, P., Slee, B. (Red.), Innovation in Forestry. CABI, Oxfordshire, 276-293. Book https://doi.org/10.1079/9781845936891.0276

Cacot, E., Bigot, M., Cuchet, E., 2006: Developing full-mechanized harvesting systems for broadleaved trees: a challenge to face the reduction of the manual workface and to sustain the supply of hardwood industries. Council on Forest Engineering (COFE) Conference Proceedings: Working Globally - Sharing Forest Engineering Challenges and Technologies Around the World, Coeur d'Alene. http://web1.cnre.vt.edu/ forestry/cofe/documents/2006/COFE_2006_Cacot_et_al.pdf (accessed 24.04.2014)
Danilović, M., Tomašević, I., Gačić, D., 2011: Efficiency of John Deere 1470D ECOIII harvester in poplar plantations. Croat. J. For. Eng. 32(2): 533-548.

Dyderski, M.K., Paz, S., Frelich, L.E., Jagodzinski, A.M., 2018: How much does climate change threaten European forest tree species distributions? Glob. Change. Biol. 24(3): 1150-1163. https://doi.org/10.1111/gcb.13925

Glöde, D., 1999: Single and double-grip harvesters productive measurements in final cutting of shelterwood. J. For. Eng. 10(2): 63-74. https://doi.org/10.1080/08435243.1999.107 02736

Jaworski, A., 1995: Silvicultural characteristic of forest trees (Charakterystyka hodowlana drzew leśnych). Gutenberg Press, Kraków, 128-139.

Karaszewski, Z., Bembenek, M., Mederski, P.S., SzczepańskaAlvarez, A., Byczkowski, R., Kozłowska, A., Michnowicz, K., Przytuła, W., Giefing, D.F., 2013: Identifying beech round wood quality - distributions and the influence of defects on grading. Drewno. Pr. Nauk. Donies. Komunik. 56(189): 3954.

Krč, J., Vranešič, U., Košir, B., 2015: Comparison of mechanized and motor-manual cutting operation in mixed stands of southern Slovenia. Šumarski list 139(7-8): 351-359.

Krpan, A, Poršinsky, T, Stankić, I., 2004: Efficiency of Mechanical Felling and Processing in Soft and Hardwood broadleaved stands; Part 3: Efficiency of harvester in natural thinning stands of hardwood broadleaf species. Šumarski list 128(9-10): 495-508.

Krpan, A., Poršinsky, T., 2004: Efficiency of Mechanical Felling and Processing in Soft and Hardwood broadleaved stands - Part 2: Efficiency of harvesters in the culture of soft broadleaf trees. Šumarski list 128(5-6): 233-244.

Labelle, E.R., Soucy, M., Cyr, A., Pelletier, G., 2016: Effect of tree form on the productivity of a cut-to-length harvester in a hardwood dominated stand. Croat. J. For. Eng. 37(1): 175183.

Lachowicz, H., 2010: Structure of silver birch wood fibers (Betula pendula Roth.) in north-eastern Poland. Forest Research Papers 71(1): 39-50. https://doi.org/10.2478/v10111010-0002-5

Mederski, P.S., 2013: The potential of harvester use for thinning operations in mixed birch-pine stands. University Press of Poznań University of Life Sciences, 109 p.

Mederski, P.S., Bembenek, M., Erler, J., Giefing, D.F., 2011: Effects of innovative thinning operation in a birch stand. Acta Scientiarum Polonorum, Silv. Colendar. Rat. Ind. Lignar 10(4): 29-38.

Mederski, P.S., Bembenek, M., Karaszewski, Z., Łacka, A., Szczepańska-Alvarez, A., Rosińska, M., 2016: Estimating and modelling harvester productivity in pine stands of different ages, densities and thinning intesities. Croat. J. For. Eng. 37(1): 27-36. 
Mederski, P.S., Bembenek, M., Karaszewski, Z., Rosińska, M., Pilarek, Z., Łacka, A., 2018a: Investigation of Log Length Accuracy and Harvester Efficiency in Processing of Oak Trees. Croat. J. For. Eng. 39(2): 173-181.

Mederski, P.S., Venanzi, R., Bembenek, M., Karaszewski, Z., Rosińska, M., Pilarek, Z., Luchenti, I., Surus, M., 2018b: Designing Thinning Operations in 2nd Age Class Pine Stands - Economic and Environmental Implications. Forests 9(6): 335. https://doi.org/10.3390/f9060335

National policy on forests, 1997: Ministry of Environment, Warsaw, $35 \mathrm{p}$.

Picchio, R., Mederski, P.S., Tavankar, F., 2020: How and How Much, Do Harvesting Activities Affect Forest Soil, Regeneration and Stands? Curr. For. Rep. 6(2): 115-128. https://doi. org/10.1007/s40725-020-00113-8

Picchio, R., Tavankar, F., Bonyad, A., Mederski, P.S., Venanzi, V., Nikooy, M., 2019: Detailed Analysis of Residual Stand Damage Due to Winching on Steep Terrains. Small-Scale For. 18(2): 255-277. https://doi.org/10.1007/s11842-019-09417-5

Report on conditions of forests in Poland 2016 (Raport o stanie lasów w Polsce 2016), 2017: The State Forests Information Centre (Centrum Informacyjne Lasów Państwowych), Warszawa, $96 \mathrm{p}$.

Schweier, J., Spinelli, R., Magagnotti, N., Becker, G., 2015: Mechanized coppice harvesting with new small-scale fellerbunchers: Results from harvesting trials with newly manufactured felling heads in Italy. Biomass and Bioenergy 72: 85-94. https://doi.org/10.1016/j.biombioe.2014.11.013

Schweier, J., Magagnotti, N., Labelle, E.R., Athanassiadis, D., 2019: Sustainability Impact Assessment of Forest Operations: a Review. Curr. For. Rep. 5(3): 101-113. https://doi. org/10.1007/s40725-019-00091-6

Spinelli, R., Hartsough, B.R., Magagnotti, N., 2010: Productivity standards for harvesters and processors in Italy. For. Prod. J. 60(3): 226-235. https://doi.org/10.13073/0015-747360.3.226
Spinelli, R., Owende, P., Ward, S., 2002: Productivity and cost of CTL harvesting of Eucalyptus globulus stands using excavator-based harvesters. For. Prod. J. 52(1): 67-77.

Spława-Neyman, S., Owczarzak, Z., 2006: Species of wood for utilisation. Birch (Użytkowe gatunki drewna. Brzoza). Łukasiewicz Research Network -Wood Technology Institute (Łukasiewicz - Instytut Technologii Drewna). Poznań. http://www.itd.poznan.pl/pl/index.php?id=37 (accessed 22.04.2014)

Suchanek, A., 2016: Variability of forest site productivity depending on soil properties, geological substratum, topography and stands characteristics in Suchedniów Forest District (Przestrzenna zmienność potencjalnej i aktualnej produkcyjności siedlisk na tle właściwości gleb, podłoża geologicznego, topografii terenu oraz cech drzewostanów na przykładzie Nadleśnictwa Suchedniów). Doctoral thesis, University of Agriculture in Krakow, 143 p.

Suchomel, C., Becker, G., Pyttel, P., 2011: Fully mechanized harvesting in aged oak coppice stands. For. Prod. J. 61(4): 290-296. https://doi.org/10.13073/0015-7473-61.4.290

Suchomel, C., Spinelli, R., Magagnotti, N., 2012: Productivity of processing hardwood from coppice forests. Croat. J. For. Eng. 33(1): 39-47.

Visser, R., Spinelli, R., 2012: Determining the shape of the productivity function for mechanised felling and fellingprocessing. J. For. Res. 17(5): 397-402.

Vusić, D., Plantak, M., Papa, I., Đuka, A., Pentek, T., Poršinsky, T., 2018: Analysing the efficiency of mechanised thinning in broadleaf stands. FORMEC 2018 Improved Forest Mechanisation: mobilizing natural resources and preventing wildfires, September 25-27, Madrid, Spain, 362-363.

Zinkevičius, R., Steponavičius, D., Vitunskas, D., Činga, G., 2012: Comparison of harvester and motor-manual logging in intermediate cuttings of deciduous stands. Turk. J. Agric. For. 36(5): 591-600. https://doi.org/10.3906/tar-1103-46

(C) 2022 by the authors. Submitted for possible open access publication under the terms and conditions of the Creative Commons Attribution (CC BY) license (http://creativecommons.org/licenses/by/4.0/). 
Authors' addresses:

Martyna Rosińska, MSc

e-mail: martyna.rosinska@up.poznan.pl

Poznań University of Life Sciences (PULS)

Faculty of Forestry and Wood Technology

Department of Forest Utilisation

Wojska Polskiego 71A, 60-625 Poznań

POLAND

and

The State Forests National Forest Holding

e-mail: martyna.rosinska@szczecinek.lasy.gov.pl

Osusznica Forest District

Osusznica 3, 77-130 Lipnica

POLAND

Assist. prof. Mariusz Bembenek, PhD

e-mail: mariusz.bembenek@up.poznan.pl

Prof. Piotr S. Mederski, PhD *

e-mail: piotr.mederski@up.poznan.pl

Poznań University of Life Sciences (PULS)

Faculty of Forestry and Wood Technology

Department of Forest Utilisation

Wojska Polskiego 71A, 60-625 Poznań

POLAND

Prof. Rodolfo Picchio, PhD

e-mail: r.picchio@unitus.it

Tuscia University

Department of Agriculture and Forest Sciences

(DAFNE)

Via S. Camillo de Lellis, 01100 Viterbo

ITALY

Zbigniew Karaszewski, PhD

e-mail: zbigniew.karaszewski@itd.lukasiewicz.gov.pl Łukasiewicz Research Network - Wood Technology Institute

Department of Wood Investigation and Application Winiarska 1, 60-654 Poznań

POLAND

Assist. prof. Andreja Đuka, PhD

e-mail: andreja.duka@sumfak.unizg.hr

University of Zagreb

Faculty of Forestry and Wood Technology

Department of Forest Engineering

Svetošimunska 23, 10002 Zagreb

* Corresponding author 